\title{
Activities, Interests, And Opinions Of Online Shoppers And Non-Shoppers
}

William R. Swinyard, (E-mail: swinyard@byu.edu), Brigham Young University Scott M. Smith, (E-mail: smsmith@byu.edu), Brigham Young University

\begin{abstract}
Internet shopping represents the launch of a new industry with corresponding levels of praise and concern. It is both the "golden child" for innovative net users, and the "evil empire" for anxious brick-and-mortar retailers. Online purchasing is growing at a dramatic rate yet the expectation for an explosion of Internet shopping has not occurred; its market share is small, at just under two percent of total U.S. retail spending.
\end{abstract}

This study has been designed to explore why online shopping is growing so fast among some households, and so slowly among others. It focuses on characterizing the fundamental motivators or satisfiers of e-retail shopping, along with its dis-satisfiers and de-motivators. And it examines lifestyles of both Web shoppers and non-shoppers to find that these are not homogeneous groups at all, but discrete market segments, each seeking distinctive benefits from the Internet.

It examines the lifestyle characteristics of online households. By means of a U.S. national probability sample of online heads-of-households, this descriptive research provides a lifestyle perspective of who is using the Internet to shop, who does not shop, and why. It is hypothesized and shown that, compared with online non-shoppers, online shoppers are younger, wealthier, have higher computer literacy, spend more time on their computer, spend more time on the Internet, and find online shopping to be easier and more entertaining.

It is further reported that shoppers and non-shoppers are involved in different online activities, and have different attitudes and opinions toward the Internet and online use. Each group is profiled and marketing implications are discussed.

\section{Introduction}

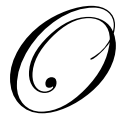

nline shopping is continuing to undergo significant growth worldwide. Responsible for the growth is the growing number of users shopping online for the first time and the increasing confidence in online properties. Yet the expectation of an explosion of Internet shopping has not occurred. The market share of online shopping is still small, at well under two percent of total retail spending (Spiwak, 2003). Most consumers have been slow to adopt it, yet few would dispute that it has a dramatic future.

However - aside from a few rudimentary demographics - little is known about the characteristics, motivators, and profile of online shoppers. This study has been designed to help fill this gap by examining some key differences between online shoppers and online non-shoppers. The study addresses the question of how online shoppers and non-shoppers are alike and how they are different - as indicated by their demographic, computer and Internet use, computer literacy, and online activities, online interests and online opinions. 


\section{Background}

\subsection{Literature}

It would be unusual not to have expectations about online shopping. For example, that online shoppers are more computer literate than non-shoppers; or that online non-shoppers have higher fears of credit card theft than shoppers, etc. A literature search of online shopper studies required identification of papers providing some depth of demographic, attitudinal, or lifestyle discussion of online shoppers or online non-shoppers. That search was conducted primarily through the CD-rom-based subscription service of WebSpirs. Although it was expected that dozens of papers would be identified as relevant to the topic of online shopper/non-shopper characteristics, a thorough review found only a handful. Results from these suggest that, compared with online non-shoppers, online shoppers...

- $\quad$ have higher levels of education, experience, and greater knowledge of the online channel (Li, Kua, and Russell, 1999)

- $\quad$ have greater Internet experience, make wider use of other non-traditional purchasing methods, have more favorable attitudes toward technology, and are more venturesome (Miyazaki and Fernandez, 2001; Siu and Cheng, 2001)

- will buy more often from and be more loyal to online vendors having lower pricing and better customer service practices (Srivnivasan, Anderson, and Ponnavolu, 2002; Swaminathan, Lepkowska, and Rao, 1999)

- $\quad$ are older and wealthier, are more convenience-oriented and less risk averse, and less brand/price conscious (Donthu and Garcia, 1999; Tan, 1999) - a view having competing perspectives. Several commercial reports (Brady, 2000; Whitfield, 1999) indicate that though the online shoppers are generally younger than nonshoppers, a result consistent with the prevailing view that technology is more quickly adopted by younger consumers.

The academic literature for Internet shopping is building but has not reached mature development, and no one study has comprehensively studied attributes that satisfy or dissatisfy potential online shoppers, and the available literature provides little insight about differences between online shoppers and non-shoppers.

The trade has reported more thoroughly than scholarly work about online shopper vs non-shopper characteristics. Unfortunately, that material is largely proprietary - inaccessible without subscription. For Forrester Research, Inc., McQuivey (2000) reported that the top reason young people do not shop online is concern about credit card security (given by 59 percent of their respondents). Credit card fears are often reported as a major deterrent to online shopping (see for example, Strauss and Frost 1999; InternetNews 1999; TechWeb 2002). Following credit card fears, McQuivey (2000) reported the deterrents to be the inability to see and touch the product (56 percent of Internet users), not trusting that online ordering will go smoothly (43 percent), having concerns about giving out personal information ( 43 percent), and the expense of shipping (43 percent).

Retail Forward's "E-Retail Intelligence System"(2000) has reported that the top reasons online users did not make an online "holiday purchase" were concerns with problems returning products (39 percent of respondents), not finding what they wanted ( 32 percent), worry that the gifts would be late (31 percent), concerns about personal privacy ( 26 percent), and about shipping charges (20 percent). That firm also reported that (2000), among online households, 52 percent of adults access it more than once a day, and another 27 percent daily.

\subsection{Hypotheses}

The existing literature provides little insight into even basic differences between online shoppers ("shoppers") and online non-shoppers ("non-shoppers"), and does little to identify lifestyle differences between those groups. Since no published reports were found that examined lifestyle studies of the differences between these two groups, in developing hypotheses we are left with but a few published precedents, augmented by our own discoveries, beliefs, and intuition as during the development of this project. The first hypothesis has been reported elsewhere (Swinyard and Smith 2003) but forms a springboard for the testing of the subsequent hypotheses. 
$\mathbf{H}_{1}$ : $\quad$ Among online households, compared with non-shoppers, online shoppers...
- $\quad$ are younger
- $\quad$ are wealthier, and
- $\quad$ are better educated

From this study's developmental work and the work reviewed above, it is also hypothesized that:

$\mathbf{H}_{2}$ : Online shoppers differ from non-shoppers in computer competency and use in that they...

- have higher "computer literacy"

- $\quad$ spend more time with their computers, and

- $\quad$ spend more time using the Internet

Finally, the lifestyles (activities, interests, and opinions) of the online shoppers and non-shoppers are examined. Informal evaluation reveals that online vs brick and mortar shopping offer different lifestyle satisfiers. For example, one might expect that online shoppers would be more adventuresome, have less free time, and have a place lower importance on personal service. However, the literature provides no clear statements or even clues about directionality of lifestyle differences, so it is hypothesized merely that,

$\mathbf{H}_{3}$ : Online shoppers' lifestyle (activities, interests, and opinions) differ from non-shoppers.

\section{Method}

Data was collected by means of a U.S. nationwide probability study conducted through the mail. The questionnaire was developed over an intensive six month period of focus-group input, 30 depth interviews, pilot-tests of measures, and two full-scale pretests among 300 students. This resulted in a four-page questionnaire having 136 individual items. The measures reported here include 14 Internet behaviors, 20 personal shopping lifestyle items, items dealing with computer and Internet use, "computer literacy," and demographics. More detail on developmental procedures, questionnaire measures, and preliminary analysis is available in Swinyard and Smith (2003).

The questionnaire was sent in early January, 2001, to a probability sample of 4000 U.S. heads-of-onlinehouseholds, with 50 percent addressed to women, 50 percent to men. The address listing of online household heads was purchased from Experian Information Solutions, Inc. (2000). A mail delivery just after the Christmas holiday was essential to the strategy of collecting data while the most significant retail period of the calendar year was still fresh in respondents' minds. By the cutoff date 1738 questionnaires had been returned, for a return rate of 43.5 percent. This high return rate is likely a function of respondents' strong in the topic, personalized handling of our outgoing letter, the authors' university-affiliation contained in the questionnaire cover-letter and return address, and a financial incentive (five chances to win $\$ 500$ ).

\section{Results}

\subsection{Demographics}

Online shoppers ("shoppers") are operationally defined as heads of households having an Internet connection at home and who reported making a personal online purchase during the holiday season of November - December, 2000. Online non-shoppers ("non-shoppers") are defined as those individuals, also in households having an Internet connection at home, who reported making no such personal purchase. Even in non-shopper homes, however, it is quite possible that another member of the household could have made an online purchase, but if the respondent head-of-household made no online purchase, he/she was still regarded as a "non-shopper." Online shoppers were found to comprise 42 percent of the sample, and non-shoppers 58 percent. 
The first hypothesis indicated that, compared with non-shoppers, online shoppers are younger, wealthier, and better educated. Shoppers, at 46.9 years are significantly younger than non-shoppers, at 49.9 years $(\mathrm{F}=23.76$ with $1 \& 1733 \mathrm{df}, \mathrm{p}<.001)$. Personal and household incomes are higher for shoppers, at $\$ 44,494$ and $\$ 65,705$, than for non-shoppers, whose incomes are $\$ 37,900$ and $\$ 56,698$ respectively (personal income: $F=26.14$ with $1 \& 1616$ df, $\mathrm{p}<.001$; household income: $\mathrm{F}=42.60$, with $1 \& 1605 \mathrm{df}, \mathrm{p}<.001$ ). And shoppers are better educated than nonshoppers. Among shoppers, 48.9 percent are college educated or better, while 38.2 percent of non-shoppers are so educated $(\mathrm{F}=24.00$, with $1 \& 1733 \mathrm{df}, \mathrm{p}<.001)$.

These results are considered in support of Hypothesis 1.

\subsection{Computer And Internet Use}

The second hypothesis deals with computer and Internet use and computer literacy. The respondents' primary computer is in use a great deal . Figure 1 shows the weekly computer hours spent by shopper and non-shopper households for several different types of use. During a typical week, the computer is in use 22.9 hours in the homes of non-shoppers and 27.4 hours in the homes of shoppers. Shoppers personally use their computers significantly more than non-shoppers - 16.7 hours per week for shoppers, and 12.9 hours for non-shoppers $(\mathrm{F}=15.82$ with $1 \& 1677 \mathrm{df}, \mathrm{p}<.001)$. Among shoppers, 9.4 weekly hours of that computer use is offline, and 11.9 hours is online. For non-shoppers the corresponding figures are 4.6 and 8.3 hours. These usage hours are significantly higher for shoppers (both online and not, at $\mathrm{p}<.01$ ). These results are considered in support of the second hypothesis.

Figure 1: Mean Internet Activity Frequency Shoppers vs. Non-Shoppers

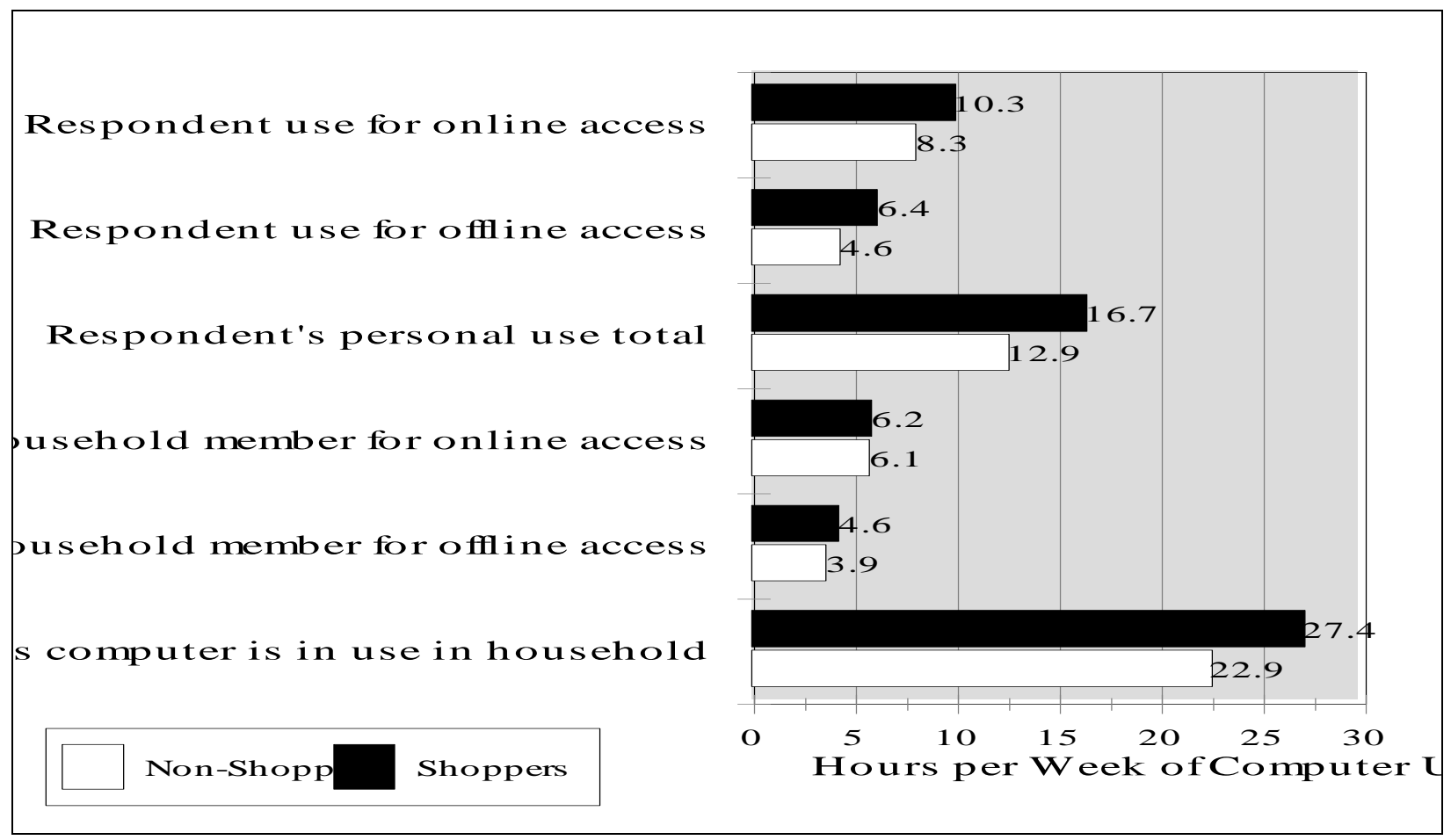

Computer literacy was measured with a newly-constructed "computer literacy index" based on the average of 12 items (alpha $=.900$ ) collected using a three-point scale ("I could not do this" [1] to "I could do this" [3]). See Figure 2 for the items. The data show shoppers to be significantly more computer literate than non-shoppers (shop- 
per mean: 2.31; non-shopper mean; 1.96; F=261.36 with $1 \& 1724 \mathrm{df}, \mathrm{p}<.001$ ). Figure 2 shows mean scores for shoppers and non-shoppers across the 12 computer literacy measures. On the chart's vertical axis is the scoring range, from 1 through 3. Points further from the center reflect its score (and higher computer literacy) on that item. Shoppers' computer literacy is significantly higher than non shoppers for every single item (at $\mathrm{p}<.001)$.

Figure 2: Mean Computer Literacy Measures Shoppers vs. Non-Shoppers

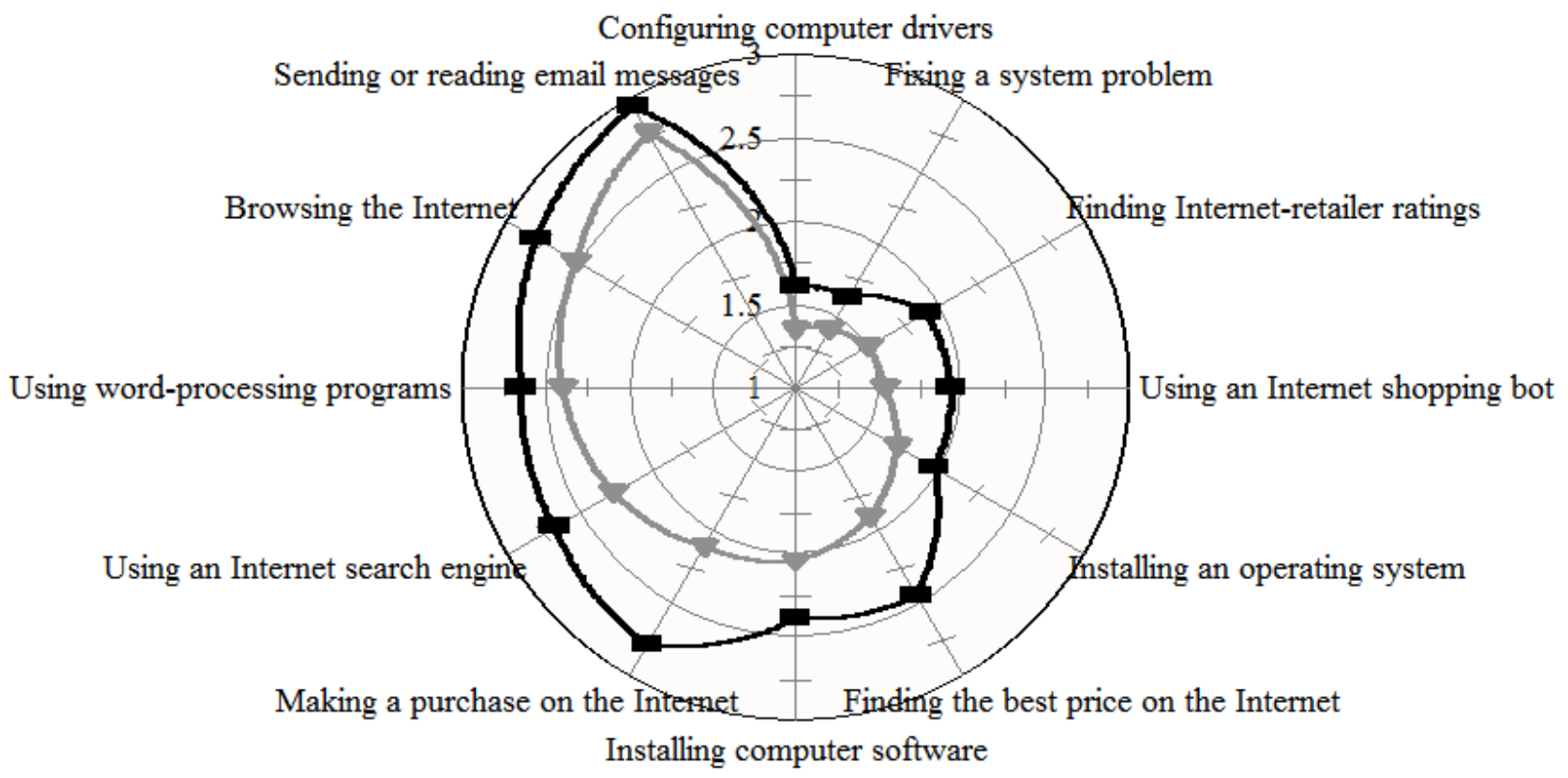

Installing computer software

\subsection{Lifestyle}

Not only do shoppers also spend more time online than non-shoppers, as shown in Figure 3, but their online access emphasizes different activities. While both groups use their online access most often for e-mail, the frequency of other online activities varies between the groups. See Figure 3, which shows the frequency of use of shoppers' and non-shoppers' computer for several activities. Except for "play games," shoppers are involved in all these activities more often than non-shoppers ("chat online" significant at $p<.01$; all other items at $p<.001$ ). Figure 4, shows the standard scores for these online activities (mean across all respondents $=0$, sd $=1$ ). That figure reveals that shoppers are far more likely than non-shoppers to use their online access for everything, but especially visiting online retailers, auction sites, reservation sites, etc. 
Figure 3: Weekly Internet Activity Frequency

Shoppers vs. Non-Shoppers

Check or send e-mail messages

Visit Internet hobby sites

Play games

Read on-line news or magazines

Visit retail merchandise sites

Conduct business-related work

Look at financial information

Find \& view images

Search for or download software

Chat on-line

Visit auction sites

Look for tickets or reservations

Visit message news-groups

Look for job opportunities

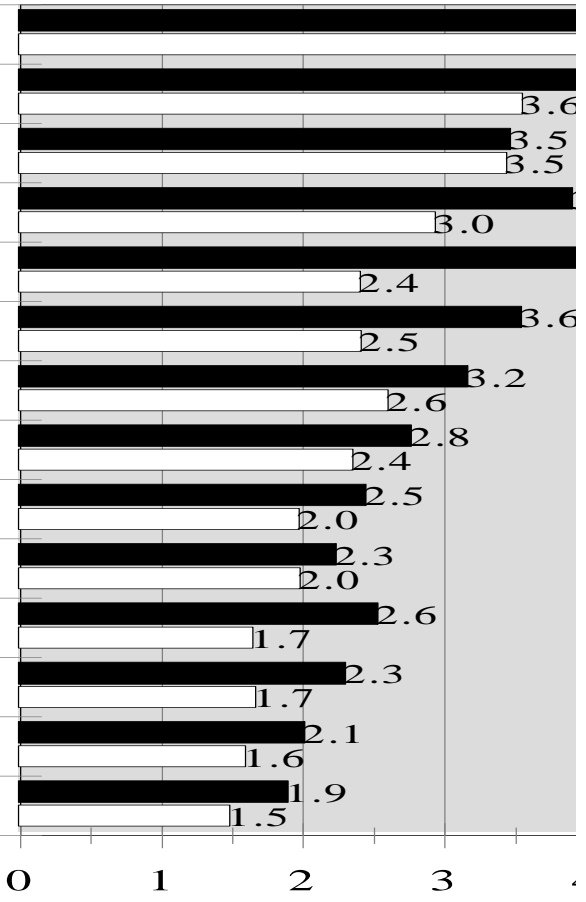

How often do you use your computer for the following activities?

$1=$ Not at all, $2=$ Under once a month, $3=$ Once a month, $4=2-3$ times a month, $5=$ Once a week, $6=2-3$ times a week, $7=$ Daily

Figure 4: Internet Activity Frequency - Standard Scores

Shoppers vs. Non-Shoppers

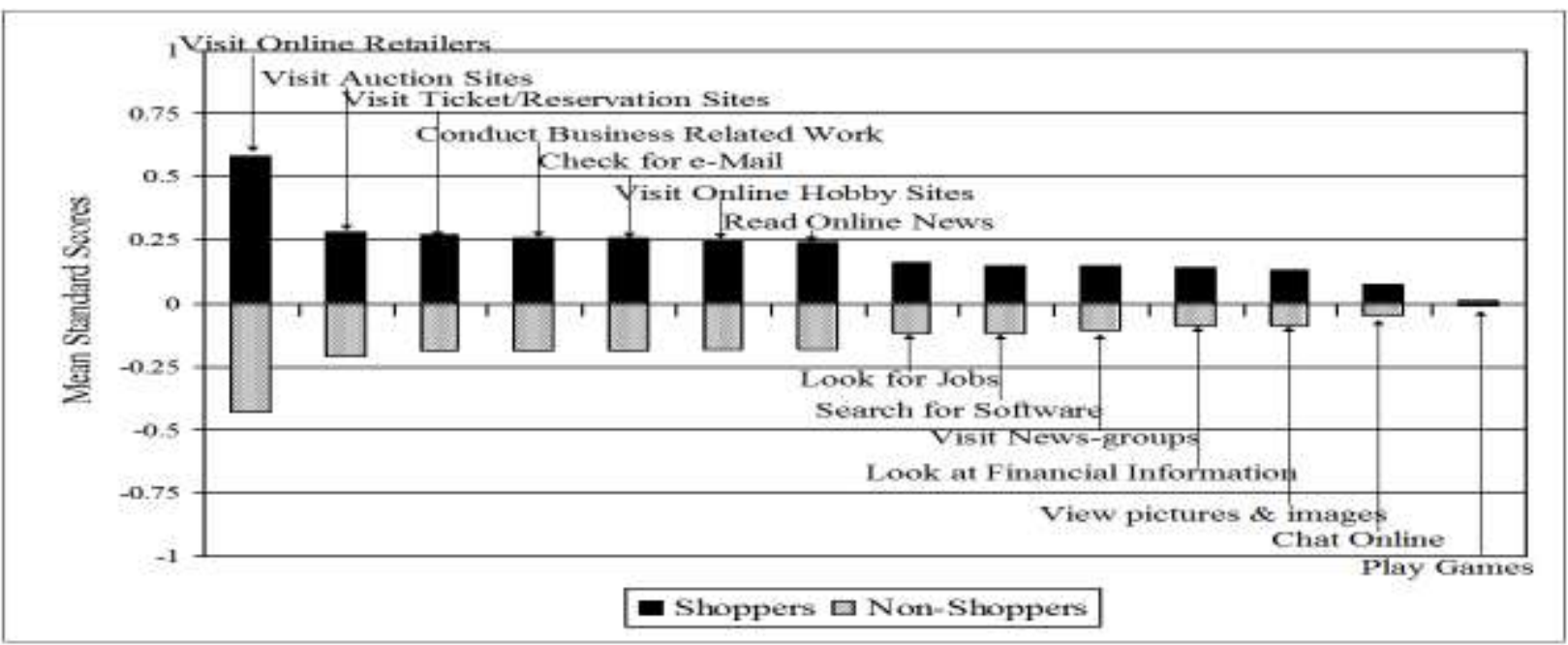

How often do you use your computer for the following activities?

Original 7-point scale $(1=$ Not at all, $2=$ Under once a month, $3=$ Once a month, $4=2-3$ times a month, $5=$ Once a week, $6=2-3$ times a week, $7=$ Daily) standardized to a scale having mean $=0$ and $\mathrm{sd}=1$ 


\subsection{Interests, Opinions}

Respondents were asked to indicate the extent to which they identified with each of 20 interest and opinion statements. These items, along with a statistical test of differences between shoppers and non-shoppers, are shown in Table 1. More than shoppers, the non-shoppers agreed with the statements, "I have old-fashioned tastes and habits," "I like the royal treatment in stores," "I prefer stores where prices are low," "I have lots of leisure time," and "I think shopping is fun." And more than the non-shoppers, the shoppers agreed with the statements, "I never have enough time to shop," "I think I am a little bit wild," "I have more money now than last year," "I like to be outrageous," and "I expect to have more money next year."

Data from these statements were factor analyzed using principal components analysis (varimax rotation) for all respondents combined. A six-factor outcome was selected on the basis of a unitary eigenvalue solution which explained 56.8 percent of the variance in the original 20 computer lifestyle items. Table 2 shows the items and factor loadings for each of the six factors, along with the authors' labels for the factors. Each label was assigned on the basis of its descriptiveness of the top several items loading most highly on the factor.

For these factors, respondent factor scores were created using Anderson-Rubin coding (mean $=0$ and sd $=$ 1). A factor score is a calculated variable whose value reveals the respondent's affiliation with a factor. For example, if a respondent had a factor score of 2.0 on the "Wild Side" factor, then this respondent's responses were two standard deviations higher than the average respondent on that factor. This tells us that the respondent agreed with the statements comprising the "Wild Side" factor more strongly than most other respondents.

The factor scores for shoppers vs non-shoppers are illustrated in Figure 5. The Figure's vertical axis shows the mean factor score value for shoppers and non-shoppers on each factor. A value of 0.0 represents the mean for each item, while the standard deviation is $\square 1.0$.

Figure 5: Mean Lifestyle Factor Scores Shoppers vs. Non-Shoppers

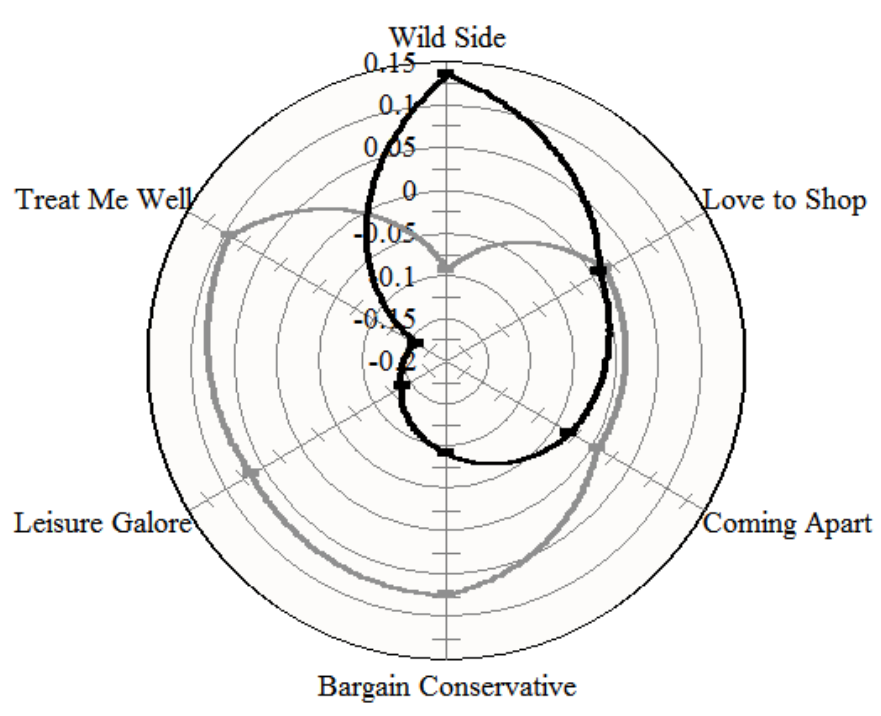

Bargain Conservative

$$
\text { Non-Shoppers } \longrightarrow \text { Shoppers }
$$


Table 1: Mean Lifestyle Item Scores

Shoppers vs. Non-Shoppers

\begin{tabular}{|c|c|c|c|c|c|c|c|c|c|c|}
\hline \multirow[b]{2}{*}{ Item } & \multicolumn{3}{|c|}{ Non-Shoppers } & \multicolumn{3}{|c|}{ Shoppers } & \multicolumn{4}{|c|}{ ANOVA } \\
\hline & Mean & $\mathbf{N}$ & Sd & Mean & $\mathbf{N}$ & Sd & SS & Df & $\mathbf{F}$ & $\mathbf{P}<$ \\
\hline It is important to me to be treated well & 4.49 & 993 & 0.68 & 4.50 & 728 & 0.66 & 0.02 & 1,1719 & 0.04 & 0.85 \\
\hline I like the royal treatment in stores & 3.38 & 992 & 1.11 & 3.11 & 725 & 1.11 & 31.39 & 1,1715 & 25.37 & 0.00 \\
\hline I have old-fashioned tastes and habits & 3.84 & 992 & 1.03 & 3.47 & 726 & 1.05 & 55.20 & 1,1716 & 51.29 & 0.00 \\
\hline I like my clothes to look up to date & 3.65 & 986 & 1.07 & 3.57 & 727 & 1.02 & 2.05 & 1,1711 & 1.87 & 0.17 \\
\hline I never have enough time to shop & 2.93 & 989 & 1.20 & 3.14 & 724 & 1.15 & 19.70 & 1,1711 & 14.15 & 0.00 \\
\hline I think I am a little bit wild & 2.19 & 987 & 1.12 & 2.40 & 724 & 1.16 & 17.54 & 1,1709 & 13.56 & 0.00 \\
\hline I think shopping is fun & 3.14 & 992 & 1.35 & 2.96 & 725 & 1.24 & 14.26 & 1,1715 & 8.42 & 0.00 \\
\hline I often buy things on impulse & 2.9 & 984 & 1.26 & 2.96 & 722 & 1.21 & 1.39 & 1,1704 & 0.91 & 0.34 \\
\hline I have lots of leisure time & 2.49 & 984 & 1.35 & 2.25 & 723 & 1.22 & 23.98 & 1,1705 & 14.29 & 0.00 \\
\hline I expect to have more money next year & 2.96 & 988 & 1.26 & 3.12 & 722 & 1.23 & 10.66 & 1,1708 & 6.86 & 0.01 \\
\hline My world is coming apart at the seams & 1.86 & 981 & 1.12 & 1.87 & 724 & 1.06 & 0.10 & 1,1703 & 0.08 & 0.78 \\
\hline I think I am a smart shopper & 3.83 & 985 & 1.02 & 3.81 & 726 & 0.91 & 1.16 & 1,1709 & 0.17 & 0.68 \\
\hline I like to be outrageous & 1.98 & 986 & 1.09 & 2.15 & 725 & 1.10 & 11.07 & 1,1709 & 9.22 & 0.00 \\
\hline I feel I get a raw deal out of life & 1.62 & 985 & 0.95 & 1.57 & 723 & 0.84 & 0.74 & 1,1706 & 0.91 & 0.34 \\
\hline I think a woman's place is in the home & 1.78 & 980 & 1.12 & 1.71 & 721 & 1.06 & 1.61 & 1,1699 & 1.34 & 0.25 \\
\hline I prefer stores where prices are low & 3.58 & 979 & 1.17 & 3.34 & 722 & 1.18 & 22.22 & 1,1699 & 16.09 & 0.00 \\
\hline I never seem to have enough money & 3.01 & 985 & 1.27 & 3.02 & 724 & 1.26 & 0.04 & 1,1707 & 0.03 & 0.87 \\
\hline I regularly read the newspaper & 3.92 & 990 & 1.33 & 3.79 & 724 & 1.32 & 7.08 & 1,1712 & 4.01 & 0.05 \\
\hline I have more money now than last year & 3.18 & 989 & 1.37 & 3.38 & 726 & 1.30 & 17.13 & 1,1713 & 9.56 & 0.00 \\
\hline When shopping I just want to get done & 2.97 & 995 & 1.27 & 2.90 & 727 & 1.24 & 1.75 & 1,1720 & 1.11 & 0.29 \\
\hline
\end{tabular}


Table 2: Lifestyle Factor Analysis

All Ss Combined

\begin{tabular}{|c|c|c|c|c|c|c|}
\hline Item & $\begin{array}{c}\text { Coming } \\
\text { Apart } \\
\end{array}$ & $\begin{array}{l}\text { Wild } \\
\text { Side }\end{array}$ & $\begin{array}{c}\text { Treat Me } \\
\text { Well }\end{array}$ & $\begin{array}{c}\text { Love } \\
\text { To Shop } \\
\end{array}$ & $\begin{array}{l}\text { Leisure } \\
\text { Galore }\end{array}$ & $\begin{array}{c}\text { Bargain } \\
\text { Conservative } \\
\end{array}$ \\
\hline My world is coming apart at the seams & 0.75 & 0.06 & 0.04 & -0.04 & -0.05 & 0.06 \\
\hline I feel I get a raw deal out of life & 0.70 & 0.15 & 0.02 & -0.06 & 0.11 & 0.16 \\
\hline I never seem to have enough money & 0.64 & 0.01 & 0.09 & 0.01 & -0.18 & 0.16 \\
\hline I like to be outrageous & 0.32 & 0.73 & -0.00 & 0.19 & -0.02 & -0.04 \\
\hline I think I am a little bit wild & 0.31 & 0.72 & 0.02 & 0.07 & -0.13 & -0.10 \\
\hline I expect to have more money next year & -0.20 & 0.66 & 0.04 & -0.02 & 0.00 & 0.22 \\
\hline I have more money now than last year & -0.46 & 0.56 & 0.12 & -0.15 & 0.06 & 0.06 \\
\hline I often buy things on impulse & 0.28 & 0.36 & 0.21 & 0.40 & 0.21 & -0.10 \\
\hline I like the royal treatment in stores & 0.09 & 0.07 & 0.74 & 0.09 & 0.08 & 0.08 \\
\hline It is important to me to be treated well & -0.02 & 0.04 & 0.66 & 0.13 & -0.14 & 0.10 \\
\hline I like my clothes to look up to date & 0.04 & 0.16 & 0.61 & 0.31 & -0.10 & -0.17 \\
\hline I have old-fashioned tastes and habits & 0.06 & -0.18 & 0.58 & -0.17 & 0.18 & 0.31 \\
\hline I regularly read the newspaper & -0.27 & 0.06 & 0.33 & -0.14 & 0.31 & -0.19 \\
\hline I think shopping is fun & 0.07 & 0.16 & 0.24 & 0.83 & 0.04 & 0.11 \\
\hline When shopping I just want to get done & 0.15 & 0.11 & 0.01 & -0.83 & -0.04 & 0.07 \\
\hline I think I am a smart shopper & -0.30 & 0.23 & 0.21 & 0.34 & -0.16 & 0.48 \\
\hline I have lots of leisure time & 0.04 & 0.10 & 0.13 & 0.07 & 0.82 & 0.06 \\
\hline I never have enough time to shop & 0.18 & 0.24 & 0.24 & -0.06 & -0.70 & -0.02 \\
\hline I prefer stores where prices are low & 0.20 & 0.08 & 0.14 & -0.01 & -0.08 & 0.70 \\
\hline I think a woman's place is in the home & 0.25 & -0.05 & -0.04 & -0.06 & 0.19 & 0.57 \\
\hline
\end{tabular}


We hypothesized merely that online non-shoppers would differ from non-shoppers with respect to their lifestyle. While we have seen that they differ in their online activities, this second part of the "lifestyle" test evaluates differences in their opinions and interests. The differences shown in Figure 5 are significant (all at $\mathrm{p}<.01$ ) for "Wild Side" (higher for shoppers than non-shoppers), "Bargain Conservative" (higher for non-shoppers), "Leisure Galore" (higher for non-shoppers), and "Treat Me Well" (higher for non-shoppers).

Looking at these data in another way, the five lifestyle statements most agreed to by non-shoppers (descending order) are:

- $\quad$ I have old-fashioned tastes and habits

- $\quad$ I like the royal treatment in stores

- I prefer stores where prices are low

- I have lots of leisure time

- I think shopping is fun

While the items most likely to be agreed with by shoppers (descending order) are:

- $\quad$ I never have enough time to shop

- I think I am a little bit wild

- $\quad$ I like to be outrageous

- $\quad$ I have more money now than last year

- I expect to have more money next year.

These results are considered in support of hypothesis 3 .

\section{Conclusion}

Whether or not online household heads will be an Internet shopper appears to depend on their attitudes toward and opinions about the Internet, and how they choose to interact with the Internet. These characteristics in turn influence how they will react to shopping on the Internet.

This research shows that online shoppers are younger, wealthier, and better educated than non-shoppers. The results reveal substantial differences between shoppers and non-shoppers in the time spent with their computers and online, and their computer literacy. Shoppers use computers more, are online more, and are more comfortable with both computer and Internet use.

By contrast, the non-shoppers use their computers substantially less, and for activities requiring a lower understanding of the technology. While they - as do shoppers - use their computer most often for email, other activities they favor are low in adventure, and require lower computer literacy.

It has also been shown that the interests and opinions of online shoppers differ substantially from nonshoppers. Several of these differences are likely due to risk aversion associated with unfamiliarity or lack of comfort with the computer and Internet. Compared with non-shoppers, online shoppers report themselves to be more contemporary in their thinking, are less concerned with personalized retail service, and have less leisure time. They consider themselves to be more adventuresome ("a little bit wild," "outrageous"), tend more to be impulse buyers, but also think of themselves as smart shoppers.

Turning non-shoppers into shoppers, and increasing the level of spending among the shoppers, are - or should be - key objectives for large online vendors. Getting non-shoppers to start shopping will require resources currently beyond the control of these vendors. To become online shoppers, non-shoppers must become more literate about computer and Internet technology. It must become both more "fun" for them as well as more engaging, as they currently find brick and mortar shopping a fun, leisurely way to fill their time. These older shoppers are fixed and conservative in their ways, and it may take a generation of younger shoppers to find online buying to be an attractive shopping experience. 
Increasing the size of the shoppers' online checkout cart is clearly the easier current objective to reach. They are already familiar with the practice, are adventuresome, have the youthful exuberance, technology orientation, and funds to be online customers. Getting them to spend more is largely a continuing improvement of those things the best online vendors do well. These include increasing the breadth of inventory, increased awareness of sites, easier site navigation, still further protection of personal information from theft, on-hand and quick delivery, immediate customer service, and painless returns-handling.

The study further suggests questions for further research. Among them are those that deal with shopper thoughts and actions once at the vendor site, including the site hit rate, visit duration, and re-visit rate, making a product selection, placing products in a cart, proceeding to actual check-out, and entry of shipping and financial information. It is further essential to discover the critical deal-makers and deal killers as potential shoppers go through the site visit, product selection, shopping cart, checkout, and final purchase. Answers to these and related questions will assist online vendors toward increasing the size of shoppers' shopping cart, and assisting non-shoppers toward becoming shoppers.

\section{Acknowledgements} study.

The authors are grateful to IBM Corporation and the JCPenney Retail Research Fund for funding this

\section{References}

1. Brady, Mick (2000). "Reality check: the state of e-commerce", E-Commerce Times. Retrieved July 11, 2000 from http://www.ecommercetimes.com/perl/story/3738.html.

2. Donthu, Naveen, and Adriana Garcia, (1999). "The Internet shopper", Journal of Advertising Research, 39(3): 52-58.

3. $\quad$ Experian (2001), http://www.experian.com.

4. InternetNews (1999). "Fear and loathing in the world of online shopping", retrieved September, 2000 from http://www.internetnews.com/ec-news/article.php/4_219101.

5. Li, Hailong, Cheng Kua, and Martha G. Russell (1999). "The impact of perceived channel utilities, shopping orientations, and demographics on the consumer's online buying behavior", Journal of Computer Mediated Communication, 5(2): NP.

6. McQuivey, James L., (2000). "Why some young consumers don't shop online", The Forrester Techno graphics Brief, June 2, 2000, Forrester Research, Inc.

7. Miyazaki, Anthony D. and Ana Fernandez (2001). "Consumer perceptions of privacy and security risks for online shopping", Journal of Consumer Affairs, 35(1): 27-44.

8. Retail Forward (2000), "E-Retail Intelligence Update, January 2000", retrieved October 2000 from http://www.pwc-ris.com/membercontent/.

9. Siu, Noel Yee Man, and May Mei-Sham Cheng (2001). "A study of the expected adoption of online shopping: The case of Hong Kong”, Journal of International Consumer Marketing, 13(3), 87-106.

10. Spiwak, Stephen J. (2003), "Retail E-Commerce Sales," Retail Update June 2003, Retail Forward, Columbus, $\mathrm{OH}$.

11. Srinivasan, Seenu; Rolph Anderson, and Kishore Ponnavolu (2002). "Consumer loyalty in e-commerce: an exploration of its antecedents and consequences", Journal of Retailing, 78(1), 41-50.

12. Strauss, Judy and Raymond Frost (1999). E-Marketing, New York: Prentice Hall.

13. Swaminathan, Vanitha, White Lepkowska, Rao Elzbietam and P. Bharat (1999). "Browsers or buyers in cyberspace? An investigation of factors influencing electronic exchange", [Electronic version]. Journal of Computer Mediated Communication, 5(2).

14. Swinyard, William R. and Scott M. Smith (2003). "Why People (Don't) Shop Online: A Lifestyle Study of the Internet Consumer", Psychology \& Marketing, 20(7), 567-597.

15. Tan, Joo-Jiuan (1999). "Strategies for reducing consumers' risk aversion in Internet shopping", Journal of Consumer Marketing, 16(2), 163-180. 
Notes 